\title{
REGULATIONS REGARDING THE PROTECTION OF EMPLOYEE RIGHTS IN MERGER, DIVISION AND CONVERSION OF TRADE COMPANIES
}

DOI: 10.17261/Pressacademia.2021.1399

RJBM- V.8-ISS.2-2021(3)-73-85

Muhammed Turkalp Seckin

Istanbul Technical University, Faculty of Management, Department of Management Engineering, Macka Campus, Istanbul, Turkey. seckint@itu.edu.tr , ORCID: 0000-0002-0866-4536

\begin{tabular}{l}
\hline Date Received: March 3, $2021 \quad$ Date Accepted: May 29, 2021 \\
\hline To cite this document \\
Seckin, M.T. (2021). Regulations regarding the protection of employees' rights in merger, division and conversion of trade companies. Research \\
Journal of Business and Management (RJBM), 8(2), 73-85. \\
Permanent link to this document: $\underline{\text { http://doi.org/10.17261/Pressacademia.2021.1399 }}$ \\
Copyright: Published by PressAcademia and limited licensed re-use rights only. \\
\hline
\end{tabular}

\section{ABSTRACT}

Purpose - The aim of this study is examining the regulations regarding protection of employee rights stated in Turkish Commercial Code (Law no: 6102) during the process of merger, division and conversion of trade companies and clarifying the uncertainties.

Methodology - The regulations stated in Turkish Commercial Law will be analyzed in comparison with the regulations in Labour Act of Turkey (Law no: 4857) and Turkish Code of Obligations (Law no: 6098), and also the Supreme Court decisions regarding the subject will be mentioned. Findings- Regulations stated in Turkish Commercial Code regarding employee rights during the process of merger, division and conversion have priority over other legal regulations. Also, these regulations are more favorable for employees. However, each structural change differs in terms of the rights provided and the scope of employees who can benefit from these rights.

Conclusion- Although there are more advantageous rights in favor of emloyees, there some uncertainties regarding the use of these rights. These uncertainties need to be addressed by evaluating the underlying reasons for the provision of rights.

Keywords: Merger, division, conversion, employee rights, transfer of the establishment

JEL Codes: K31, K22, K41

\section{TiCARET ŞiRKETLERININ BİRLEŞME, BÖLÜNME VE TÜR DEĞişTiRMELERINDE işÇi HAKLARININ KORUNMASINA İLiŞKIN DÜZENLEMELER}

\section{ÖZET}

Amaç - Bu çalışmanın amacı ticaret şirketlerinin birleşme, bölünme ve tür değiştirme sürecinde iş̧̧i haklarının korunmasına yönelik olarak 6102 sayılı Türk Ticaret Kanunu'nda yer alan düzenlemelerin incelenmesi ve belirsizlik bulunan noktaların açıklığa kavuşturulmasıdır.

Yöntem - 6102 sayılı Türk Ticaret Kanunu'nda yer alan hükümler, 4857 sayılı İş Kanunu ve 6098 sayılı Türk Borçlar Kanunu’nda yer alan düzenlemeler ile karşılaştırmalı olarak ele alınacak, aynı zamanda konu ile ilgili verilmiş olan Yargıtay kararlarına da değinilecektir.

Bulgular- Birleşme, bölünme ve tür değiştirme sürecinde işçi hakları ile ilgili olarak Türk Ticaret Kanunu'nda yer alan düzenlemeler, diğer kanunlara nazaran önceliklidir. Ayrıca söz konusu düzenlemeler iş̧̧iler bakımından daha lehe hükümlerdir. Ancak her yapısal değişiklik, sağlanan haklar ve bu haklardan yararlanabilecek iş̧̧ilerin kapsamı bakımından farklılık arz etmektedir.

Sonuç- Iş̧̧iler lehine daha avantajlı haklar yer alsa da söz konusu hakların kullanımı ile ilgili bazı belirsizlikler göze çarpmaktadır. Bu belirsizliklerin hakların sağlanmasının altında yatan nedenler ile değerlendirilerek giderilmesi gerekmektedir.

Anahtar Kelimeler: Birleşme, bölünme, tür değiştirme, iş̧̧i hakları, işyeri devri JEL Kodları: K31, K22, K41 


\section{GíRiş}

Türk Hukukunda işyeri devrinin işçilere yönelik sonuçları 4857 sayılı İş Kanunu madde 6'da, ik kapsamında olmayıp da hizmet sözleşmesiyle çalışanlara yönelik sonuçları 6098 sayılı Türk Borçlar Kanunu madde 428'de düzenlenmiştir. 6012 sayılı Türk Ticaret Kanunu madde $178^{\prime}$ de ise bölünmeye dayalı olarak gerçekleşen işyeri devri neticesinde işçilere sağlanan haklar bakımından bazı özel düzenlemelere yer verilmiştir. TTK madde $158^{\prime}$ de yapılan atıf dolayısıyla birleşmede, TTK madde 190 'da yapılan atıf dolayısıyla da tür değiştirmede, TTK madde 178 hükmü uygulama alanı bulmaktadır. TTK madde 178'de yer alan düzenlemelerin kaynağı 30.10.2013 tarihli İsviçre Birleşme, Bölünme, Tür Değiştirme ve malvarlığı Devrine İlişkin Federal Kanunu ile söz konusu kanunda yapılan atıflar dolayısıyla İsviçre Borçlar Kanunu'dur.

İ madde 6 ile kıyaslandığında, TTK madde $178^{\prime}$ de işçiler yönünden daha geniş haklara yer verildiği görülmektedir. Özellikle iş ilişkilerinin geçmesi bakımından işçilere tanınan itiraz hakkının, Anayasa madde 48' de düzenlenen sözleşme özgürlüğü kapsamında son derece yerinde olduğu kabul edilmekte, ik madde $6^{\prime}$ da böyle bir hükme yer verilmemiş olması ise eleştirilmektedir. Ayrıca devreden ve devralan işverenin birlikte sorumluluklarının kapsamının genişletilmiş olması, işçilere teminat talep etme hakkının tanınması ve ortakların kişisel sorumlulukları bakımından getirilen düzenlemeler TTK madde 178'i, ík madde 6'dan ayırmaktadır. Ancak TTK madde 178'de yer alan her hükmün, tüm yapısal değişiklikler yönünden geçerli olduğunu söylemek mümkün değildir.

Çalışmamız birleşme, bölünme ve tür değiştirmede işçilerin korunmasına dair getirilen hükümlerin incelenmesini konu edinmiştir. Bu kapsamda öncelikle işyeri devrinde genel hüküm niteliğinde olan İ madde 6 incelenmiş, í madde 6 ile TTK madde 178 özelgenel hüküm bağlamında karşılaştırılmıştır. Ardından birleşme, bölünme ve tür değiştirme halleri kısaca açıklanmıştır. Son olarak da TTK kapsamında yapısal değişikliler bakımından işçilerin korunmasına yönelik getirilen düzenlemeler, genel anlamda şirket alacaklılarına sağlanan haklar ile işçilere sağlanan özel nitelikteki hakların karşılaştırılması suretiyle ele alınmıştır.

\section{4857 SAYILI iş KANUNU KAPSAMINDA IŞYYERi DEVRi VE işçiLER YÖNÜNDEN SONUÇLARI}

\section{1. İşyeri Devri ve İşyeri Devrinin Iş̧̧iler Yönünden Sonuçları}

İşyeri devri íK madde 6 ile TBK madde 428'de düzenlenmiş olup İK madde 6 ile TBK madde 428'nin benzer hükümler içerdiği görülmektedir (Senyen Kaplan, 2013: 25; Özkaraca, 2012: 107). Genel olarak işverenin değişmesi işverenin ölümü, iflası, işyerinin devletleştirilmesi veya özelleştirilmesi, birleşme, bölünme veya tür değiştirme hallerinde gerçekleşebilmektedir (Çelik/Caniklioğlu/Canbolat, 2019: 142). İ madde 6 kapsamında işyeri devrinden söz edilebilmesi için ise devirde işyerinin ekonomik birliğinin korunması gerekmektedir (Süzek, 2019: 196).

IK madde 6/1 uyarınca işyeri veya işyerinin bir bölümü hukuki bir işleme dayalı olarak başka birine devredildiğinde mevcut iş sözleşmeleri bütün hak ve borçları ile birlikte devralana geçmektedir. İş̧inin hizmet sözleşmesinin esas alındığı haklarda işçinin devreden işveren yanında çalışmaya başladığı tarih esas alınmalıdır (Süzek, 2019: 200). Ayrıca İ madde 6/3 uyarınca devreden işveren devirden önce doğmuş ve devir tarihinde ödenmesi gereken borçlardan devralan işveren ile birlikte iki yıl boyunca müteselsilen sorumludur.

1475 sayılı İş Kanunu madde 14/2 uyarınca devreden işveren işçiyi çalıştırdığı sürelerle ve devir esnasındaki iş̧̧inin aldığı ücret seviyesiyle işçinin kıdem tazminatından sorumlu olmaya devam etmektedir. İ madde $6 / 5$ uyarınca devralan işveren veya iş̧̧inin sırf devir nedeniyle iş sözleşmesini feshetme hakları bulunmamaktadır (Çelik/Caniklioğlu/Canbolat, 2019: 146). Bu nedenle işçinin devir nedeniyle iş sözleşmesini feshederek kıdem tazminatı talep etmesi mümkün değildir (Süzek, 2019: 200).

\subsection{Türk Ticaret Kanunu Madde 178 'in İş Kanunu Madde 6 Karşısındaki Konumu}

Bölünme halinde işyeri devrinin iş̧̧iler yönünden sonuçları TTK madde 178'de düzenlenmiştir. Söz konusu düzenleme, TTK madde $158^{\prime}$ de yapılan atıf dolayısıyla birleşmeye, madde 190'da yapılan atıf dolayısıyla ise tür değiştirmeye uygulanmaktadır (Senyen Kaplan, 2013: 25; Özkaraca, 2012: 111). TTK madde 178 ile IK madde 6 karşılaştırıldığında, TTK madde 178'de yer alan hükümlerin işçiler bakımında çok daha avantajlı düzenlemeler olduğu göze çarpmaktadır. Bu husus TTK'nın yapım sürecinde hazırlanan TBMM Adalet Komisyonu Raporu'nda da ifade edilmiştir (Ekmekçi, 2011: 157-159). Raporda, getirilen düzenleme "...iş̧̧i alacaklarının teminat altına alınması yönünden Iş Kanununun 6 ıncı maddesinden daha iyi ve toplumsal yönü güçlü..." şeklinde nitelendirilmiştir. Diğer yandan TTK madde 178/4'te yer alan hükmün konuyla ilgisinin bulunmadığı ve gereksiz olduğu da doktrinde belirtilmektedir (Ekmekçi, 2011: 157). 
TTK madde 178 'de yer alan farklı düzenlemelerin ilki, işçilere tanınan itiraz hakkıdır. TTK madde 178/1 uyarınca işçilerle yapılan hizmet sözleşmeleri, ancak işçi itiraz etmediği takdirde devralan işverene geçmektedir. Diğer bir farklılık devreden ve devralan işverenlerin müteselsil sorumluluklarının kapsamına ilişkindir. İ madde 6'daki düzenlemeden farklı olarak devreden işveren, devir tarihinden sonra muaccel olan alacaklardan da TTK madde 178/3 uyarınca müteselsil sorumlu olabilmektedir. Ayrıca işçilere alacaklarının teminat alınmasını talep etmek hakkı tanınmıştır (Senyen Kaplan, 2013: 25). Aynı zamanda IK madde 6'da yer alan 2 senelik zamanaşımı süresine TTK madde 178'de yer verilmemiştir (Özkaraca, 2012: 112).

IK madde 6 ile TTK madde 178 kıyaslandığında, TTK madde 178'in birleşme, bölünme ve tür değiştirme halleri ile sınırlı olarak daha özel nitelikte bir hüküm olduğu kabul edilmelidir (Süzek, 2019: 204; Astarlı, 2013: 70). Nitekim TTK madde 178'in özel nitelikte bir düzenleme olduğuna dair ifadeler TTK'nın genel gerekçesi ile Adalet Bakanlığı Komisyon Raporu'nda da yer almaktadır (Albayrak Zincirlioğlu, 2014: 41). İK madde 6 hükmü ise tüm işyeri devirlerini kapsayan genel nitelikte bir düzenlemedir (Kayık Aydınalp, 2017: 81).

\section{TiCARET ŞiRKETLERINDE YAPISAL DEĞişiKLIKLER}

\subsection{Birleşme}

Birleşme TTK madde 136-161 arasında düzenlenmiştir. Bir devralan ortaklık ile bir veya daha fazla devredilen ortaklık arasında birleşme sözleşmesine göre gerçekleştirilen iradi bir işlemdir. Devredilen ortaklıkların malvarlıkları külli halefiyet ilkesi bağlamında devredilen ortaklıkların genel kurullarının birleşmeyi onaylayan kararlarının ticaret siciline tescili üzerine kendiliğinden devralana geçmektedir. Devredilen ortaklıklar ise infisah etmektedirler. Birleşme neticesinde devralan şirketin payları devredilen şirket ortaklarınca kendiliğinden iktisap edilmektedir (Poroy/Tekinalp/Çamoğlu, 2014: 99).

TTK'ya göre birleşme "devralma şeklinde birleşme" ve "yeni kuruluş şeklinde birleşme" olarak iki şekilde gerçekleşmektedir. Devralma şeklinde birleşmede mevcut bir ticaret ortaklı̆ı, bir veya birden çok ticaret ortaklığını devralmaktadır. Yeni kuruluş şeklindeki birleşmelerde ise birleşen ortaklıklar birleşme için kurulmuş bulunan yeni bir ticaret ortaklığının bünyesinde birleşmektedirler. TTK madde 137'de izin verilen birleşme çeşitleri sınırlı sayı prensibiyle sayılmıştır. Ayrıca TTK madde 194'te ticari işletmelerin birleşmeleri düzenlenmiştir (Poroy/Tekinalp/Çamoğlu, 2014: 102-103). TTK madde 194, TBK madde 202 ile karşılaştırıldığında bir şirket başka bir şirketin, derneğin veya gerçek kişinin işletmesini devraldığı takdirde TBK madde 202'nin; bir şirket başka şirkete ait işletmeyi devraldığı ve o şirket sona erdirildiği takdirde TTK madde 194'ün uygulanacağını söylemek mümkündür (Albayrak Zincirlioğlu, 2014: 13-14).

\subsection{Bölünme}

Bölünme TTK madde 159-179 arasında düzenlenmiştir. Bölünme, bir ortaklığın malvarlığının tamamının veya bir kısmının ya da bazı kısımlarının o ortaklıktan ayrılarak bir bütün halinde mevcut veya yeni kurulacak bir ortaklığa devredilmesidir. Karşılığında mevcut veya yeni kurulan ortaklıkların payları bölünen ortaklığın ortaklarınca veya bölünen ortaklık tarafından iktisap edilmektedir. Bölünme "tam bölünme" veya "kısmi bölünme" olarak iki şekilde gerçekleşmektedir. Tam bölünen ortaklık infisah etmektedir. Kısmi bölünmede ise bölünen ortaklık sona ermemekte, kedisinde kalan malvarlığı ile faaliyetine devam etmektedir. Geçerli bölünmeler TTK madde 160'ta sınırı sayı prensibi ile sayılmıştır (Poroy/Tekinalp/Çamoğlu, 2014: 148-149).

\subsection{Tür Değiştirme}

Tür değiştirme gerçekleştirilirken şirket tasfiye edilmemekte, malvarlığı bütünlüğü korunmakta, ekonomik ayniyet ve devamlılı sürdürülmektedir (Özkaraca, 2012: 120). Nitekim TTK madde 180'de yeni türe dönüştürülen şirketin eskisinin devamı olduğu ifade edilmiştir. 6102 sayılı TTK sisteminde külli halefiyet ilkesinin geçerli olduğu, işveren değişikliğinin yaşandığı "devredici tür değiştirme" değil, tersi nitelikte olan biçim değiştirici tür değiştirme kabul edilmiştir. Tür değişikliğinde işveren değişikliği söz konusu olmadığından iş̧̧ilerin itiraz hakkının bulunmadığı kabul edilmektedir (Poroy/Tekinalp/Çamoğlu, 2014: 168; Senyen Kaplan, 2013: 26-27; Alp, 2012: 54). Aynı zamanda tür değişikliğinde bir işyeri devri söz konusu olmadığından, işçiler yönünden ík madde 6'nın da uygulanma imkanı bulunmamaktadır (Özkaraca, 2012: 115). 


\section{BíRLEŞME, BÖLÜNME VE TÜR DEĞişTiRMEDE IŞçiLERIN KORUNMASINA YÖNELIK HÜKÜMLER}

\section{1. İş̧inin İtiraz Hakkı}

\subsubsection{Genel Olarak}

TTK madde $178 / 1$ 'de öngörülen itiraz hakkı yapısal değişiklik sonucunda işçilerin iş sözleşmelerinin yeni işverene geçmesinin engellenmesine yönelik iş̧̧iler lehine getirilmiş bir düzenlemedir (Özkaraca, 2012: 128). Doktrindeki bir görüşe göre itiraz hakkının kaynağı Anayasa madde 48'dir. Bu bağlamda iş̧̧iyi istemediği bir işveren ile çalışmaya zorlamak onun kişilik haklarını, sözleşme ve çalışma hürriyetini ihlal anlamına gelecektir (Astarlı, 2013: 86). İtiraz hakkı ile işçiye tanımadığı bir işveren ile çalışmayı reddetme imkanı tanınmıştır (Senyen Kaplan, 2013: 27). İşçiye tanınan itiraz hakkının yapısal değişikliği önleyici bir etkisi ise bulunmamaktadır (Senyen Kaplan, 2013: 28). İşçiler itiraz edebilmek için herhangi bir sebebe ihtiyaç duymamaktadırlar (Alp, 2012: 61; Astarlı, 2013: 90). Ancak doktrindeki bir görüşe göre yapısal değişiklikler işçinin durumunu ağırlaştırmıyorsa, işçileri itiraz hakkı tanınması gereksizdir. Çünkü işçiler için önemli olan işverenin değil, işyeri ve çalışma koşullarının değişmesidir (Ekmekçi, 2011: 159).

\subsection{2. İtiraz Hakkının Kullanııma Şekli ve Zamanı}

İtiraz hakkının hangi işverene karşı yöneltileceğine ve kullanılma zamanına dair TTK madde 178'de açık bir düzenleme bulunmamaktadır. Öncelikle itiraz hakkının hangi işverene yöneltilmesi gerektiği hususunda doktrindeki bir görüşe göre itirazın devreden veya devralan işverene karşı yapılması yeterli kabul edilmelidir (Çelik/Caniklioğlu/Canbolat, 2019: 147; Senyen Kaplan, 2013: 28). İtiraz için şekil şartı öngörülmemiştir. Iş̧çi itiraz hakkını yazılı veya sözlü olarak kullanabilecek olsa da (Gündoğdu/Kaplan, 2011: 1018) itirazın yazılı yapılması ispat açısından kolaylık sağlayacaktır (Senyen Kaplan, 2013: 27). Isççinin iş sözleşmesinde yer verilecek bir hüküm ile önceden itiraz hakkından vazgeçmesi mümkün değildir (Astarlı, 2013: 93). Ancak yapısal değişiklik ile ilgili bilgi sahibi olduktan sonra işçiden alınan kabul neticesinde itiraz hakkının düştüğü kabul edilmektedir (Senyen Kaplan, 2013: 27). Diğer bir değişle itiraz hakkından feragat, itiraz hakkını doğuran olayın gerçekleşmesinden sonra mümkündür (Kayık Aydınalp, 2017: 153).

İtiraz yenilik doğuran bir hak niteliğini haiz olduğundan dolayı şarta bağlanamayıp, tek taraflı olarak geri alınamamaktadır (Astarlı, 2013: 89). Ancak itirazın karşı tarafa ulaşmadan veya ulaşmakla birlikte karşı taraf öğrenmeden geri alınabilmesi; hata, hile, tehdit nedeni ile irade beyanları sakatlanan işçilerin iptal müessesesine başvurabilmeleri mümkündür (Kayık Aydınalp, 2017: 146). Doktrinde bir görüşe göre tarafların anlaşmaları halinde itiraz geri alınabilmeli ve iş sözleşmesi aynı şekilde devam etmelidir (Astarlı, 2013: 89). Diğer bir görüşe göre ise fesih beyanından dönülmesinin kabul edilmesi halinde yeni bir sözleşme kurulmaktadır (Eren, 2012: 68).

İtiraz hakkının kullanılma zamanına yönelik doktrinde farklı görüşler bulunmaktadır. İlk görüşe göre işveren değişikliği ík madde 22 uyarınca işçi bakımından esaslı değişiklik kabul edilmelidir ve İ madde 22'deki gibi, işçi yapısal değişiklikten haberdar olduğu andan itibaren 6 işgünü içinde itiraz hakkını kullanmalıdır (Alp, 2012: 63). Diğer bir görüşe göre işçinin itiraz hakkı bölünme anına kadardır (Gündoğdu/Kaplan, 2011: 1018). Bu görüş uyarınca iş̧̧inin itiraz hakkının birleşme anına kadar yapılması gerektiği de ileri sürülebilecektir. Başka bir görüşe göre itiraz süresi dürüstlük kuralına göre belirlenmelidir (Süzek, 2014: 327-328). Diğer bir görüşe göre işçi yapısal değişikliği öğrendiği andan itibaren 1 ay içinde itiraz etmelidir (Özkaraca, 2012: 130). Doktrindeki farklı bir görüşe göre, yapısal değişiklik sonucunda sosyal planın (Bkz. aşağıda 3/E) uygulanmasının etkisini göstermeye başladığı andan itibaren işçilerin itiraz hakkını kullanmaları mümkündür (Poroy/Tekinalp/Çamoğlu, 2014: 165).

Doktrinde itiraz hakkının ne zaman kullanılacağına dair farklı görüşler bulunmakla birlikte, tüm görüşlerin ortak noktası işçinin yapısal değişiklikten haberdar olduğu andan itibaren itiraz süresinin başlayacağını kabul etmeleridir. Ancak işçilerin yapısal değişiklikten ne zaman haberdar olacaklarına dair TTK madde 178 'de bir açıklık bulunmamaktadır. Mehaz İsviçre Borçlar Kanunu madde 333'te işverenlerin iş̧̧ileri devrin sebebi ve iş̧̧iler üzerindeki hukuki, ekonomik ve sosyal etkileri hususlarında bilgilendirmekle yükümlü olduğu hüküm altına alınmıştır (Senyen Kaplan, 2013: 28). Bu nedenle de işçilerin itiraz süresinin yapılacak bilgilendirmeden itibaren başlayacağı kabul edilmektedir (Özkaraca, 2012: 131).

Her ne kadar işçilerin itiraz haklarını kullanabilmeleri için bu hususta bilgi sahibi olmaları gerekiyor olsa da TTK'da yapısal değişikliklerde işverenin işçileri bilgilendirme yükümlülüğüne yer verilmemiştir (Astarlı, 2013: 88; Mollamahmutoğlu/Astarlı/Baysal, 2014: 286). Bu nedenle işçilerin yapısal değişiklikten sonra haberdar olmaları durumunda itiraz süresinin o andan itibaren başlayacağı kabul edilmektedir (Astarlı, 2013: 92). Birleşmede madde 157/2'de, bölünmede ise madde 
174 'te alacaklıların korunması başlığı altında yapılacak ilanlar hüküm altına alınmıştır. Kanaatimizce söz konusu ilanların işçilerin yapısal değişiklikten haberdar olmaları anı olarak kabul edilebilmeleri mümkündür.

\subsection{3. İtirazın Niteliği ve Sonuçları}

TTK madde 178/2'de işçi itiraz ettiği takdirde hizmet sözleşmesinin kanuni işten çıkarma süresinin sonunda sona ereceği, tarafların ise o tarihe kadar sözleşmeden kaynaklanan sorumluluklarını yerine getirmekle yükümlü oldukları hüküm altına alınmıştır (Senyen Kaplan, 2013: 28). Doktrindeki baskın görüşe göre iş sözleşmesinin bu şekilde sona ermesi işçi veya işveren feshi anlamına gelmeyip, kanun gereğidir (Süzek, 2014: 329; Mollamahmutoğlu/Astarlı/Baysal, 2014: 287). Bu bağlamda itiraz neticesinde iş sözleşmeleri bakımından kendine özgü bir sona erme halinin bulunduğu kabul edilmektedir (Mollamahmutoğlu/Astarlı/Baysal, 2014: 287). Ancak fesih olarak kabul edilmemesi hali, iş sözleşmesinin sona ermesinin sonuçları bakımından bir takım sorunlara neden olabilecek niteliktedir.

Maddede yer alan "kanuni işten çıkarma süresi" iş hukuku terminolojisine yabancı bir kavramdır. Söz konusu kavramın TTK madde 178/2'de yer alıyor olması, doktrinde mehaz İsviçre Borçlar Kanunu madde 333'ün çevirisinde yapılan bir yanlışlığa dayandırılmaktadır (Alp, 2012: 63; Kayık Aydınalp, 2017: 273). Bu nedenle kavram ile ík madde 17'de yer alan kanuni bildirim sürelerinin kastedildiği kabul edilmektedir (Süzek, 2014: 328; Astarlı, 2013: 94; Alp, 2012: 63; Gündoğdu/Kaplan, 2011: 1018). Böylelikle işçi itiraz ettiği takdirde iş sözleşmesi IK madde 17' de yer alan yasal bildirim sürelerinin sonunda sona ermektedir (Süzek, 2014: 328; Özkaraca, 2012: 133).

TTK madde $178 / 2$ 'de kanuni sürelerden bahsedildiği için, taraflar daha uzun bildirim süreleri belirlemiş olsalar dahi ík madde 17'deki süreler esas alınmalıdır (Süzek, 2014: 328). Ayrıca madde metninde dikkat çeken diğer bir husus belirli ve belirsiz süreli sözleşmeler arasında ayrım yapılmamış olmasıdır. Bu bağlamda iş sözleşmesi ister belirli, ister belirsiz süreli olsun, işçinin kıdemine bağlı olarak hesaplanacak bildirim süresi sonunda iş sözleşmesinin sona ereceği kabul edilmektedir (Senyen Kaplan, 2013: 28; Mollamahmutoğlu/Astarlı/Baysal, 2014: 289; Özkaraca, 2012: 133). İşçinin yapısal değişiklik gerçekleşmeden önce itiraz hakkını kullandığı ve kanuni bildirim süresinin değişiklik gerçekleşmeden önce sona erdiği varsayımında, iş sözleşmesinin en erken devir tarihinde sona erdiği kabul edilmelidir (Özkaraca, 2012: 133). Belirli süreli iş sözleşmesinin süresi, bildirim süresinden daha önce sona eriyorsa, sözleşmenin bitiş tarihi esas alınmalıdır (Mollamahmutoğlu/Astarlı/Baysal, 2014: 289; Alp, 2012: 64).

Kanuni bildirim süresinin bitimi devir tarihinden sonraki bir tarihe denk geldiği takdirde, TTK madde 178/2 uyarınca tarafların iş sözleşmesinden doğan hak ve yükümlülükleri sözleşmenin sona ereceği tarihe kadar devam etmektedir. Her ne kadar işçi yeni işveren ile çalışmama yönündeki iradesini ortaya koymuş olsa da sürenin sonuna kadar devralan işveren sözleşmenin tarafı olmaktadır (Süzek, 2014: 328; Alp, 2012: 64). Bu durumda işverenin ík madde 17/4'de yer alan ve işverenin bildirim sürelerine ait ücreti peşin vermek suretiyle iş sözleşmesini feshedebileceğine dair hakkı kullanıp kullanamayacağına dair doktrinde görüş ayrılığı bulunmaktadır. Bir görüşe göre itiraz sonucunda iş sözleşmesinin sona ermesi bir fesih değildir. İ madde 17/4 ise süreli fesih halinde işverene tanınmış bir haktır. Bu nedenle itiraz halinde uygulanması mümkün değildir (Astarlı, 2013: 99; Özkaraca, 2012: 134). Diğer bir görüşe göre ise işçi itiraz hakkını yeni işveren ile çalışmamak amacıyla kullanmaktadır. Bu nedenle işverenin peşin ödeme yoluyla iş sözleşmesini sona erdirebilmesi iki tarafın da yararına olacaktır (Alp, 2012: 65). Tarafların anlaşarak bildirim süresinden önce sözleşmeyi sona erdirmeleri ise her zaman mümkündür.

İtiraz neticesinde iş sözleşmesinin sona ermesinin fesih niteliğinde kabul edilmemesi, işçilerin kıdem tazminatına hak kazanıp kazanmayacakları hususunda belirsizliğe yol açmaktadır. İşçilerin kıdem tazminatına hak kazanabilecekleri haller 1475 sayılı iş Kanunu madde 14 'te düzenlenmiştir. Maddede sayılan haller dışında iş̧̧ilerin kıdem tazminatına hak kazanmaları mümkün değildir. TTK madde 178 uyarınca yapılan itiraz neticesinde iş sözleşmesinin sonra ermesi işçi veya işveren tarafından sözleşmenin feshi niteliğinde olmadığından, 1475 sayılı ík madde 14'ün kapsamına da girmemektedir. Bu hususta doktrindeki bir görüşe göre kanunda bilinçsiz boşluk bulunmaktadır ve 1475 sayılı í madde 14 kıyasen uygulanmalıdır (Özkaraca, 2012: 137; Alp, 2012: 66; Süzek, 2014: 329; Mollamahmutoğlu/Astarlı/Baysal, 2014: 287). Çünkü işçinin sözleşmesini feshetmek suretiyle kıdem tazminatına hak kazanmadan işten ayrılması zaten her zaman mümkündür (Astarlı, 2013: 96).

TBMM Adalet Komisyonu Raporu'nda da belirtildiği üzere hüküm işçiye daha üstün haklar sağlamak üzere getirildiğinden TTK madde 178 'e dayanarak itiraz hakkının kullanılması neticesinde iş sözleşmesinin sona ermesi halinde işçi kıdem tazminatına hak kazanmalıdır (Süzek, 2014: 329; Senyen Kaplan, 2013: 28). Kıdem tazminatından da ziyade işçi tüm haklarını alarak işyerinden ayrılmalıdır (Poroy/Tekinalp/Çamoğlu, 2014: 165; Astarlı, 2013: 96). Ancak Yargıtay 9. HD 2018 yılında verdiği bir kararda "Somut uyuşmazlıkta, davacı iş̧̧i Türk Ticaret Kanunu'nun ilgili hükümlerine dayanarak iş yeri devrine muvafakat etmemiş ve iş akdini 
feshettiğini bildirmişse de iş kanunun 6. maddesinde işyeri devrinin işçi yönünden haklı fesih oluşturmayacağı hükmü karşısında işyerine devrine itiraz eden işçinin haklı feshinden söz edilemeyeceğinden kıdem tazminat talebinin reddi gerekir" hükmü ile kıdem tazminatı talebini reddetmiştir (Yargıtay 9. HD’nin 10.12.2018 tarih ve 2015-28060/22719 sayılı kararı, www.lexpera.com.tr).

TTK madde 178 kapsamında itiraz neticesinde iş sözleşmesinin sona ermesinin işçi veya işveren tarafından yapılmış bir fesih olarak kabul edilmemesinin diğer bir sonucu işsizlik sigortası yönünden ortaya çıkmaktadır. İşsizlik sigortası geçici bir süreliğine işine kaybeden işçiye sağlanan, ücret kaybını gidermeye yönelik parasal bir yardımdır. İşçinin işsizlik ödeneğine hak kazanabilmesi için ise kanunda sayılar şartların gerçekleşmiş olması aranmaktadır. TTK madde 178 kapsamında iş sözleşmesinin sona ermesi ise bu şartlar arasında yer almamaktadır. Kıdem tazminatıyla ilgili yapılan açıklamalar işsizlik sigortası bakımından da kabul edilmeli ve işçi işsizlik sigortasından faydalanmaya da hak kazanmalıdır. Nitekim mehaz İsviçre Borçlar Kanunu madde 333'te itiraz fesih benzeri bir hak olarak kabul edilmekte ve işçiler işsizlik sigortasında faydalanabilmektedirler (Kayık Aydınalp, 2017: 194).

Son olarak itirazın sonuçları rekabet yasağı sözleşmesinin durumu bakımından değerlendirilirken, yapısal değişiklik TBK madde 447/2 kapsamında işverene yüklenen bir neden olarak değerlendirilmekte ve bu nedenle itiraz halinde iş sözleşmesinin sona ermesi ile birilikte rekabet sözleşmesinin de sona ereceği ifade edilmektedir (Kayık Aydınalp, 2017: 193).

\subsubsection{Geçerli Olduğu Yapısal Değişiklikler ve Faydalanabilecek İş̧iler}

Birleşme halinde işçilerin itiraz haklarının olup olmadığı hususunda ikili bir ayrım yapılması gerekmektedir. Devralma şeklinde birleşmelerde (Bkz. yukarda 2/A) devredilen şirket iş̧̧ileri bakımından bir devir söz konusu iken, devralan şirket çalışanları açısından aynı yorumun yapılması mümkün değildir. Bu nedenle devralma şeklindeki birleşmelerde devralan şirket işçilerinin itiraz hakkı bulunmamaktadır (Alp, 2012: 62). Ancak yeni kuruluş türündeki birleşmelerde (Bkz. yukarda 2/A) devralan pozisyonundaki yeni kurulan şirket, devredilen tüm şirketlerdeki işçiler bakımından yeni işveren konumundadır. Bu halde ise tüm işçilerin itiraz hakkının bulunduğu söylenebilecektir (Özkaraca, 2012: 117). TTK madde 194'te TTK madde 158'e yapılan atıf dolayısıyla da ticari işletmelerin birleşmesinde de işçilerin itiraz haklarının olduğunu söylemek mümkündür.

Bölünme halinde de işçilerin itiraz haklarının olup olmadığı hususunda yine ikili bir ayrım yapılması gerekmektedir. TTK madde 159 uyarınca tam bölünüp (Bkz. yukarda 2/B) devredilen şirket sona ermektedir. Tam bölünmede tüm iş̧̧iler için işveren değişikliği söz konusu olmaktadır. Bu nedenle tüm işçilerin itiraz haklarının var olduğu kabul edilmektedir. Kısmi bölünme (Bkz. yukarda 2/B) halinde ise TTK madde 159 uyarınca bölünen şirketin malvarlığının bir bölümü diğer şirketlere devredilmektedir. Bu nedenle devredilmeyen bölümde çalışan işçiler bakımından herhangi bir değişiklik söz konusu olmadığından bu işçilerin itiraz haklarının olmadığı kabul edilmektedir (Kayık Aydınalp, 2017: 144). Ancak İstanbul BAM 14. HD’nin 2018 tarihli kararına konu olan bir olayda, davalı şirketin kısmi bölünme suretiyle tüm malvarlığını diğer şirkete aktardığı, devredilmeyen bölümde kalan işçilerin daha sonra alacaklarını talep ettiklerinde davalı şirketin herhangi bir malvarlığına rastlanılmadığı görülmektedir (İstanbul BAM 14. HD’nin 11.07.2018 tarih ve 236/750 sayılı kararı, www.lexpera.com.tr). Kanaatimizce, buna benzer durumların önüne geçilmesi için devredilmeyen bölümde çalışmaya devam işçilerin de itiraz haklarının bulunduğunu kabul etmek yerinde olacaktır.

Tür değiştirme gerçekleştirilirken şirket tasfiye edilmemekte, malvarlığı bütünlüğü korunmakta, ekonomik ayniyet ve devamlılık sürdürülmektedir (Özkaraca, 2012: 120). Nitekim TTK madde 180'de yeni türe dönüştürülen şirketin eskisinin devamı olduğu ifade edilmektedir. 6102 sayılı TTK sisteminde külli halefiyet ilkesinin geçerli olduğu, işveren değişikliğinin yaşandığı "devredici tür değiştirme" değil, tersi nitelikte olan biçim değiştirici tür değiştirme kabul edilmiştir (Poroy/Tekinalp/Çamoğlu, 2014: 168; Senyen Kaplan, 2013: 26-27; Alp, 2012: 54). Tür değişikliğinde işveren değişikliği söz konusu olmadığından işçilerin itiraz hakkının bulunmadığı kabul edilmektedir (Poroy/Tekinalp/Çamoğlu, 2014: 164; Kendigelen, 2012: 157; Alp, 2012: 62). Nitekim birleşmeler bakımından TTK madde 158'de yapılan atıfta "iş ilişkileri hakkında" TTK madde 178 uygulanır tabiri yer alırken, tür değiştirme bakımından TTK madde 190'da yapılan atıfta "iş sözleşmelerinden doğan borçlar hakkında" TTK madde 178 uygulanır tabiri kullanılarak bir bakıma tür değiştirmede iş̧̧ilerin itiraz hakkının bulunmadığı kanun koyucu tarafından da dikkate alınmıştır (Kayık Aydınalp, 2017: 166).

\subsection{Müteselsil Sorumluluk}

\subsubsection{Genel Olarak}

TTK madde 178'deki düzenleme ile devreden ve devralan işverenlerin müteselsil sorumluluklarının kapsamı, í madde 6’ya göre daha geniş tutulmuştur (Çelik/Caniklioğlu/Canbolat, 2019: 147). í madde 6'da devreden işverenin sorumluluğu devirden önce muaccel olmuş alacaklar ile sınırlı iken TTK madde 178 devirden sonra muaccel hale gelmiş alacakları da kapsamaktadır. 


\subsection{2. İçerik ve Süre Olarak Kapsamı}

Müteselsil sorumluluğun hangi zaman aralığı dahilinde muaccel olan alacakları kapsadığının belirlenmesi hususunda TTK madde $178 / 3^{\prime}$ te işçinin itiraz etmesi veya etmemesine göre farklı düzenlemeler getirilmiştir. İşçi itiraz ettiği takdirde eski işveren ile devralan işveren bölünmeden önce muaccel olmuş alacaklar ile işçinin itirazı sebebi ile sözleşmenin sona erdiği tarihe (Bkz. yukarda 3/A/3) kadar geçen sürede muaccel olacak alacaklardan müteselsilen sorumludurlar. Sürenin başlangıcı olarak devir tarihi değil, işçinin itirazının işverene ulaştığı an kabul edilmelidir (Alp, 2012: 64) ve hem belirli hem de belirsiz süreli iş sözleşmeleri bakımından kanuni bildirim süreleri esas alınmalıdır (Özkaraca, 2012: 149). Doktrindeki bir görüşe göre devreden işverenin devirden sonraki borçlardan sorumlu olabilmesi için, borcun devirden önce doğmuş olması gerekmektedir (Mollamahmutoğlu/Astarlı/Baysal, 2014: 288; Alp, 2012: 69-70). Ancak diğer bir görüşe göre TTK madde 178/3'ün açık ifadesi karşısında borcun doğum anı değil, muaccel hale geldiği tarih esas alınmalıdır (Özkaraca, 2012: 150).

İş̧i itiraz etmediği takdirde eski işveren ile devralan işveren, bölünmeden önce muaccel olmuş alacaklar ile hizmet sözleşmesinin normal olarak sona ereceği tarihe kadar geçen sürede muaccel olacak alacaklardan müteselsilen sorumludurlar. Bu bağlamda belirli süreli sözleşmeler bakımından belirli sürenin sonuna kadar doğacak alacakların müteselsil sorumluluğun kapsamına girdiği kabul edilmelidir (Alp, 2012: 70; Özkaraca, 2012: 149). Ancak belirsiz süreli sözleşmeler bakımından normal olarak sona erme hali iş hukukunda ölüm olarak kabul edilmektedir. Bu nedenle doktrinde müteselsil sorumluluk bakımından makul bir sürenin tespiti gündeme gelmiştir. Bir görüşe göre sözleşme devir sırasında feshedilseydi, bildirim süreleri sonunda sözleşme en erken ne zaman sona erecek ise müteselsil sorumluluğun sınırı o tarih olmalıdır (Alp, 2012: 70; Özkaraca, 2012: 149). Bu durumda kanuni fesih süresinden söz edilmediği için artırılmış süreler var ise bu süreler dikkate alınmalıdır (Özkaraca, 2012: 149).

Devreden işveren devirden sonraki alacaklardan da müteselsilen sorumlu olduğundan dolayı belirli süreli iş sözleşmesi belirli sürenin sonunda veya itiraz nedeniyle sona erdiği takdirde yıllık ücretli izin alacağı gibi alacaklardan devreden işveren de sorumlu olacaktır (Özkaraca, 2012: 152). Belirsiz süreli sözleşmelerin itiraz nedeniyle sona ermesinde de aynı durum söz konusudur (Özkaraca, 2012: 152). Ancak kıdem tazminatı bakımından 1475 sayılı İ madde 14'ün özel hüküm olduğu kabul edilerek, devreden işverenin kıdem tazminatı sorumluluğunun işçiyi çalıştırdığı süreler ve devir sırasında işçinin aldığı ücret seviyesiyle sınırlı olduğu kabul edilmelidir (Alp, 2012: 69).

iK madde $6 / 3^{\prime}$ te devreden işverenin müteselsil sorumluluğuna dair özel bir zamanaşımı süresi yer almaktadır. Hükme göre "...devir halinde, devirden önce doğmuş olan ve devir tarihinde ödenmesi gereken borçlardan devreden ve devralan işverenler birlikte sorumludurlar. Ancak bu yükümlülüklerden devreden işverenin sorumluluğu devir tarihinden itibaren iki yıl ile sınırlıdır". Örneğin, işverenin ödenmemiş ücretten sorumluluğu ík madde 32 uyarınca 5 yıllık zamanaşımı süresine tabi iken, devir ile birlikte bu süre iki yıla inmektedir (Çelik/Caniklioğlu/Canbolat, 2019: 144). TTK madde 178'de yer alan düzenlemede böyle bir sınır öngörülmediğinden dolayı sorumluluk kapsamındaki tüm alacaklar kendi zamanaşımı kurallarına tabidirler (Senyen Kaplan, 2013: 28; Mollamahmutoğlu/Astarlı/Baysal, 2014: 289; Alp, 2012: 69).

\subsubsection{Geçerli Olduğu Yapısal Değişiklikler ve Faydalanabilecek İşçiler}

Birleşmenin, devralma şeklinde birleşme ile yeni kuruluş şeklinde birleşme olarak iki türünün bulunduğu ve iki türde de devredilen şirketin infisah ettiği yukarda açıklanmıştır (Bkz. yukarda 2/A). Devredilen şirketin infisah etmesi nedeniyle de önceki işverenin varlığından söz edilemeyeceğinden dolayı müteselsil sorumluluk hükümlerinin uygulanması birleşme halinde mümkün değildir (Özkaraca, 2012: 117). Aynı durum tam bölünme halinde de söz konusudur. Tür değişikliğinde ise işveren değişikliği söz konusu olmadığından dolayı aralarında müteselsil sorumluluk doğacak farklı işverenler bulunmamaktadır.

Müteselsil sorumluluğun uygulanabileceği tek ihtimal kısmi bölünme halidir (Mollamahmutoğlu/Astarlı/Baysal, 2014: 187-188; Antalya BAM 9. HD'nin 11.04.2019 tarih ve 98/728 sayılı kararı, www.lexpera.com.tr). Devreden ve devralan ortaklıklar arasında müteselsil sorumluluk vardır (Özkaraca, 2012: 147-148). IK madde 6/4'te yer alan "tüzel kişiliğin birleşme veya katılma ya da türünün değişmesiyle sona erme hallerinde birlikte sorumluluk hükümler uygulanmaz" hükmü de aslında bir bakıma malumun ilanı halidir. Çünkü tüzel kişilik ortadan kalkacağı için zaten sorumluluk söz konusu olmayacaktır (Süzek, 2014: 319). Müteselsil sorumluluk ile ilgili düzenlemeden yararlanabilecek işçiler ise kısmi bölünen şirketin devredilen kısmında çalışan işçilerdir (Senyen Kaplan, 2013: 28; Alp, 2012: 68). 


\subsubsection{Bölünmeye Katılan Şirketlerin İkinci Derece Sorumluluğu}

TTK madde 176/1'de "bölünme sözleşmesi veya bölünme planıyla kendisine borç tahsis edilen şirket, bu suretle birinci derecede sorumlu bulunan şirket, alacaklıların alacaklarını ifa etmezse, bölünmeye katılan diğer şirketler, ikinci derecede sorumlu şirketler, müteselsilen sorumlu olurlar" düzenlemesi yer almaktadır. İkinci derecede sorumlu olan şirketlerin takip edilebilmeleri için, alacağın teminat altına alınmamış ve birinci derecede sorumlu şirketin; iflas etmiş, konkordato süresi almış, aleyhinde yapılan bir icra takibinde kesin aciz vesikası alınmasının şartları doğmuş, merkezi yurt dışına taşınmış ve artık Türkiye'de takip edilemez duruma gelmiş veya yurt dışındaki merkezinin yeri değiştirilmiş ve bu sebeple hukuken takibi önemli derecede güçleşmiş olması gerekmektedir.

\section{3. İş̧ilerin Teminat Talep Etme Hakkı}

\subsubsection{Genel Olarak}

TTK madde 157 'de birleşmede, TTK madde 174 'te ise bölünmede alacaklıların alacaklarının teminat altına alınmasına yönelik esaslar düzenlenmiştir. Buna göre yapılması öngörülen ilanlar sonrasında birleşmede birleşmenin geçerlilik kazanmasından itibaren 3 ay, bölünmede ise alacaklılar için yapılması öngörülen ilandan itibaren 3 ay içinde alacaklıların başvurması üzerine alacakların teminat alınması veya şirketin tercihine bağlı olarak diğer alacaklıların zarara uğramayacaklarının anlaşılması üzerine ödenmesi gerekmektedir (Şener, 2012: 129-149; Senyen Kaplan, 2013: 30). TTK madde 175/2 uyarınca bölünmede, alacaklıların alacaklarının tehlikeye düşmediğinin ispatı halinde teminat yükümlülüğü kalkmaktadır.

Teminat altına alınması gereken alacaklar birleşme ve bölünmeden önce muaccel olan alacaklardır (Şener, 2012: 129-149). Ancak doktrinde birleşmeden sonra muaccel olarak alacakların da teminat altına alınabileceği ifade edilmiştir (Poroy/Tekinalp/Çamoğlu, 2014: 138). TTK madde $178 / 5$ 'te getirilen ve işçilerin alacaklarının teminat altına alınması düzenleyen hüküm ile teminat kapsamının genişletildiğini söylemek mümkündür. Ayrıca TTK madde 178'de yer verilen düzenleme ile TTK madde 157 veya TTK madde 175 uyarınca alacakların tümünü kapsayan tek teminat verilen durumlarda, işçilerin TTK madde 178'e dayanarak ayrı ve özel bir teminat talep edebilmeleri mümkün hale gelmiştir. TTK madde $178^{\prime}$ de teminat talebi hususunda düzenlemelere yer verilmediğinden dolayı, TTK madde 157 ve 174'te öngörülen hükümlerden faydalanılması gerekmektedir (Kayık Aydınalp, 2017: 267).

Birleşmelerde devredilen şirket infisah ettiğinden dolayı teminatın devralan şirket tarafından verildiği kabul edilmektedir (Kayık Aydınalp, 2017: 253). Bölünmelerde ise teminat bölünmeden önce gösterileceğinden (Özkaraca, 2012: 169) dolayı teminat talebi devreden şirkete yöneltilmelidir (Kayık Aydınalp, 2017: 253). Teminat talebi bakımından herhangi bir şekil şartı öngörülmemiştir. Teminatın türü ayni veya şahsi olabileceği gibi; taşınır veya taşınmaz üzerinde rehin hakları, 3. kişilere ait malvarlıkları üzerinde ayni teminat, ödeme gücü olan 3. kişinin kefaleti teminat olarak gösterilebilecektir (Özkaraca, 2012: 170). Alacaklıların birleşmeye veya bölünmeye engel olma hakları bulunmamaktadır (Şener, 2012: 129-147). Diğer yandan işçilerin ya da alacaklıların korunmasına dair kanun maddelerinin TTK madde 192'de düzenlenen iptal davasında iptal nedeni olarak ileri sürülebilmesi de mümkün değildir (Narbay/Kesici, 2015: 152). Ancak bölünmede teminat yükümlülüğü bölünmenin ön şartı niteliğinde olduğundan yerine getirilmediği takdirde şirketin bölünmesine engel teşkil edeceği kabul edilmelidir (Çakrak, 2017: 113).

\subsection{2. İçerik ve Süre Olarak Kapsamı}

TTK madde 178/5'te “işçiler muaccel olan ve birinci fıkrada öngörüldüğü şekilde muaccel olacak alacakların teminat altına alınmasını isteyebilirler" hükmü yer almaktadır. Ancak TTK madde 178/5'te yapılan atıf 1. fıkraya değil 3. fıkraya yapılmış kabul edilmelidir (Kendigelen, 2016: 61). TTK madde 178/3'te ise eski işveren ile devralanın, işçinin bölünmeden evvel muaccel olmuş alacakları ile hizmet sözleşmesinin normal olarak sonra ereceği veya işçinin itirazı sebebiyle sona erdiği tarihe kadar geçen sürede muaccel olacak alacaklarından müteselsilen sorumlu olacakları düzenlenmiştir. Yukarda hizmet sözleşmesinin normal olarak sona ermesi (Bkz. yukarda 3/B/2) ile itiraz sebebiyle sona ermesi (Bkz. yukarda 3/A/3) halleri bakımından yapılan açıklamalar bu başlık altında da geçerlidir.

\subsubsection{Geçerli Olduğu Yapısal Değişiklikler ve Faydalanabilecek İşçiler}

TTK madde 158'deki atıf nedeniyle işçilerin alacaklarının teminat alınmasına dair özel düzenleme niteliğinde olan TTK madde 178/5 hükmü birleşmelerde de uygulanmalıdır. Ancak birleşmede devralan ortaklık işçilerinin TTK madde 178/5 uyarınca teminat talep etme hakları bulunmamaktadır (Senyen Kaplan, 2013: 30; karşı görüş için bkz. Özkaraca, 2012: 165). Bölünme halinde de tam 
bölünmede tüm işçilerin TTK madde 178/5 uyarınca teminat talep etme hakları mevcutken, kısmi bölünmede devreden şirket iş̧̧ilerinin TTK madde 178/5 uyarınca teminat talep etme haklarının bulunmadığı söylenebilecektir (Kayık Aydınalp, 2017: 265; Senyen Kaplan, 2013: 30; karşı görüş için bkz. Özkaraca, 2012: 166). Böyle bir kabul söz konusu işçilerin itiraz haklarının bulunmadığına dair görüşle aynı doğrultuda olacaktır. Ancak devreden şirketin içinin boşaltılmasına yönelik olarak yukarda yer verilen çekince, bu noktada da geçerlidir (Bkz. yukarda 3/A/4).

Söz konusu hükme göre teminat talep etme hakkı bulunmayan işçilerin, TTK madde 147 ve TTK madde 174 hükümleri uyarınca daha dar bir kapsamda teminat talep edebilecekleri kabul edilmelidir. Diğer yandan doktrinde, birleşme ve bölünmede genel olarak alacakların teminat altına alınmasını düzenleyen TTK madde 157 ile 174'te teminat hakkından yararlanacak olanlar için “birleşmeye katılan şirketlerin alacaklıları” ibaresi kullanılmış olduğundan, gerek devreden gerekse devralan şirketin işçilerinin de teminat talep etme hakkına sahip olduklarına dair bir görüş de ileri sürülmüştür (Çakrak, 2017: 110). Yapısal değişikliğe itiraz etmiş olan işçilerin de teminat talep etme haklarının olduğu kabul edilmelidir (Özkaraca, 2012: 165). Tür değiştirme bakımından ise doktrindeki bir görüşe göre tür değiştirmede, birleşme ve bölünmeden farklı olarak işçi haricindeki diğer alacaklılar bakımından da teminat talep etme hakkı verilmediğinden dolayı, işçilerin TTK madde 178/5'e dayanarak teminat talep etmek hakları bulunmamaktadır (Özkaraca, 2012: 166; karşı görüş için bkz. Çakrak, 2017: 110-111).

\subsection{Ortakların Kişisel Sorumluluğu}

\subsubsection{Genel Olarak}

TTK madde 236 ' da kollektif şirketlerde tüm ortakların, TTK madde 325'te komandit şirketlerde komandite ortakların, TTK madde 564 'te ise sermayesi paylara bölünmüş komandit şirketlerde bir ya da birkaç ortağın alacaklılara karşı şahsi sorumlu oldukları hüküm altına alınmıştır. Söz konusu ortaklık türleri, anonim veya limited şirket türlerine dönüştükten sonraki dönemde ortakların şahsi sorumluluklarından bahsedilmesi mümkün olmayacaktır. Bu ihtimali göz önünde bulunduran kanun koyucu, birleşmeler bakımından TTK madde 158/1'de bazı şartlar altında devredilen şirketin borçlarından birleşmeden önce sorumlu olan ortakların sorumluluklarının birleşmeden sonra da devam edeceğini hüküm altına almıştır. Ayrıca doktrindeki bir görüşe göre şahsi sorumluluğun devamı, birleşmelerde TTK madde 141 uyarınca ayrılma akçesi alarak şirketlerden ayrılan ortaklar için de geçerlidir (Mollamahmutoğlu/Astarlı/Baysal, 2014: 285; Özkaraca, 2012: 160). TTK'da bölünmeler için ayrılma akçesine yer verilmemiş olsa da bölünmeye katılan ortaklıklarla ayrılmak isteyen ortaklar arasında varılan anlaşmanın bölünme sözleşmesine konulması ile sadece devralma yoluyla yapılan bölünmelerde ayrılma akçesi ödenebileceği de doktrinde belirtilmiştir (Poroy/Tekinalp/Çamoğlu, 2014: 156).

Bölünme ve tür değiştirme bakımından da kanun içinde yapılan atıflar nedeniyle TTK madde 158 uygulama alanı bulacaktır. Tüm alacaklıların başvurabileceği TTK madde 158'in yanında, iş ilişkilerinin geçmesi bakımından, bölünmede devreden şirketin bölünmeden önce şirket borçlarından dolayı sorumlu olan ortaklarının belirli şartlar altında bölünmeden sonra da sorumlu olmaya devam edeceklerine dair bir hüküm TTK madde 178/6' da yer almaktadır. Yine birleşme ve tür değiştirme bakımından da kanun içinde yapılan atıflar nedeniyle TTK madde 178 uygulama alanı bulacaktır. TTK madde 158 hükmü tüm alacakıların başvurabileceği bir imkan iken, TTK madde 178 hükmü işçiler için getirilmiş özel bir düzenlemedir. TTK madde 194/2'de bir ticari işletmenin bir ticaret şirketine dönüşebileceği düzenlenmiştir. Bu durumda tür değiştirme sonrasında ticari işletmenin ortaklarının sorumluluklarının devam ettiğini söylemek de mümkündür (Çakrak, 2017: 120).

\subsection{2. İçerik ve Süre Olarak Kapsamı}

Tüm alacaklıların başvurabileceği TTK madde 158'de, ortakların şahsi sorumluluklarının devam edebilmesi için borcun birleşme kararından önce doğmuş olması veya borcu doğuran nedenlerin birleşme tarihinden önce oluşması gerekmektedir. Ayrıca borcun birleşme ilanı tarihinden itibaren 3 yıl geçince zamanaşımına uğrayacağı, borç ilan tarihinden sonra muaccel olur ise zamanaşımının muacceliyet tarihinden itibaren başlayacağı belirtilmektedir.

TTK madde 178/6' da "devreden şirketin bölünmeden önce şirket borçlarından dolayı sorumlu olan ortakları, hizmet sözleşmesinden doğan ve intikal gününe kadar muaccel olan borçlarla, hizmet sözleşmesi normal olarak sona ermiş olsaydı muaccel hale gelecek olan veya işçinin itirazı sebebiyle hizmet sözleşmesinin sona erdiği ana kadar doğacak olan borçlardan müteselsilen sorumlu olmaya devam ederler" hükmü yer almaktadır. Yukarda hizmet sözleşmesinin normal olarak sona ermesi (Bkz. yukarda 3/B/2) ile itiraz sebebiyle sona ermesi (Bkz. yukarda 3/A/3) halleri bakımından yapılan açıklamalar bu başlık altında da geçerlidir. 
TTK madde 178/6'da, TTK madde 158'den farklı olarak 3 yıllık zamanaşımı süresi öngörülmemiştir. Ancak TTK madde 177 'de ortakların kişisel sorumlulukları bakımından TTK madde 158'in uygulanacağı hüküm altına alındığından dolayı yine 3 yıllık zamanaşımı süresinin uygulama alanı bulacağı ifade edilmektedir (Çakrak, 2017: 122). Ayrıca TTK madde 158'de borcun birleşme kararından önce doğmuş olması veya borcu doğuran nedenlerin birleşme tarihinden önce oluşması gerekmekte iken, TTK madde 178 'de hizmet sözleşmesi normal olarak sonra ermiş olsaydı muaccel hale gelecek, itiraz sebebiyle hizmet sözleşmesinin sona erdiği tarihe kadar ise muaccel olma şartı aranmadan yalnızca doğacak borçlardan ortakların sorumlu olmaya devam edecekleri hüküm altına alınmıştır (Özkaraca, 2012: 159-160).

\subsubsection{Geçerli Olduğu Yapısal Değişiklikler ve Faydalanabilecek İşçiler}

Ortakların şahsi sorumluluklarının devamına dair TTK madde 158 hükmü her ne kadar birleşmeyle ilgili maddelerin arasında yer alsa da, TTK madde 158/4'de yapılan atıf nedeniyle iş ilişkilerinin geçmesi hususunda ortakların kişisel sorumluluklarının devamı bakımından TTK madde 178 uygulama alanı bulacaktır. Kollektif ve komandit şirketlerin TTK madde 137 uyarınca devredilen şirket olarak sermaye şirketleri ile birleşmeleri mümkün olduğundan, birleşmeden önce şahsi sorumlulukları bulunan ortaklar bakımından TTK madde 158 ile TTK madde 178'in uygulanması son derece doğaldır. Devralma yoluyla birleşmede devralan şirket işçilerinin TTK madde 178'e dayanmaları mümkün olmasa da TTK madde 158'e dayanmaları mümkündür.

Bölünme TTK'da yalnızca sermaye şirketleri ile kooperatiflere bakımından öngörülmüştür. Sermaye şirketleri ile kooperatiflerde ise şirket borçlarından sorumlu ortak bulunmadığından dolayı TTK 178/6’nın bölünmede uygulama alanının bulunmadığı söylenebilecektir (Özkaraca, 2012: 114). Kollektif ve komandit şirketlerin bölünmesi TTK madde 160 uyarınca mümkün değildir. Ancak doktrinde belirtildiği üzere sermayesi paylara bölünmüş komandit şirketlerin veya ana sözleşmelerinde varlığın borçları karşılamaya yetmediği takdirde ortakların şahsen sorumlu olacaklarına dair hüküm bulunduğu durumlarda kooperatiflerin bölündüğü durumlarda TTK madde 158 ve madde 178 uygulanmalıdır (Özkaraca, 2012: 161; Kayık Aydınalp, 2017: 259). Kısmi bölünme halinde de devralan mevcut şirket işçilerinin TTK madde 178'e dayanmaları mümkün olmasa da TTK madde 158'e dayanmaları mümkündür.

Bazı hallerde şirketler tür değiştirme ile sınırlı sorumluluğun geçerli olduğu şirket türlerine dönüşebilmektedirler. Her ne kadar "biçim değiştirici tür değiştirme" halinde işveren değişikliği yaşanmadığı ve bu nedenle işçinin itiraz, teminat talebi haklarının bulunmadığı, müteselsil sorumluluk hükümlerinin uygulanamayacağı kabul ediliyor olsa da, ortakların kişisel sorumluluklarının bulunduğu şirket türlerinin, sınırlı sorumluluk esasının kabul edildiği şirket türlerine dönüşmesi halinde ortakların kişisel sorumluluklarının devam etmesi TTK madde 190' da TTK madde 158'e yapılan atıf ile sağlanmıştır (Özkaraca, 2012: 123). Örneğin, bir kollektif veya komandit şirketin, bir sermaye şirketine dönüşmesi durumunda kişisel sorumlu ortakların sorumlulukları işçilere karşı devam edecektir. Bu halde kollektif şirket ortakları ve komandite ortaklar, devralan şirket ile birlikte müteselsil sorumlu olmaktadırlar (Özkaraca, 2012: 113).

TTK madde 194 'te ticari işletmelerin bir ticaret şirketiyle, ticaret şirketi tarafından devralınmak suretiyle birleşebileceği hüküm altına alınmış ve uygulanacak kanun maddeleri arasında TTK madde 158'de sayılmıştır. Bu bağlamda ticari işletmelerin birleşmesi durumunda da TTK madde 158' de TTK madde 178'e yapılan atıf dolayısıyla ortakların şahsi sorumluluklarına dair hükümlerin uygulanması gerekecektir (Senyen Kaplan, 2013: 29).

\subsection{Birleşme ve Bölünme Raporları Kapsamında Sosyal Plan}

Birleşme bakımından TTK madde 147'de, Bölüme bakımından ise TTK madde 169'da birleşme ve bölünme raporlarının, yapısal değişikliğin işçiler üzerindeki etkilerine ve mümkünse veya varsa sosyal planın içeriğine yer verilmesi gerektiği öngörülmüştür. Hükümlerde yer alan sosyal plan bakımından kullanılan mümkünse veya varsa ifadeleri nedeniyle doktrindeki bir görüşe göre sosyal plan öngörülmüş olsa da zorunlu değildir (Mollamahmutoğlu/Astarlı/Baysal, 2014: 290; Özkaraca, 2012: 116). Ancak birleşme ve bölünme raporlarına işçileri etkileyen durumları yazılması gerekmektedir (Mollamahmutoğlu/Astarlı/Baysal, 2014: 290). Doktrindeki diğer bir görüşe göre kural birleşme raporunda sosyal plana yer verilmesidir ve yer verilmediği takdirde bu durumun sebebi açık ve anlaşılır şekilde ortaya konmalıdır (Gündoğdu/Kaplan, Sosyal Plan, 2011: 168).

Birleşme ve bölünmenin işçiler üzerindeki etkileri personel yapısındaki, işçi sayısındaki, işyeri organizasyonundaki, ücret ve iş süreleri gibi çalışma koşullarındaki değişiklikler neticesinde ortaya çıkan farklılıklar iken, sosyal planın içeriğini ekonomik nedenlerle ile yoğun iş̧̧i çıkarmaları ve olumsuz sonuçlarını sınırlamak için iş̧̧ilerin yeniden istihdamını sağlayan tedbirler ile çalışma süresi düzenlemeleri oluşturmaktadır (Mollamahmutoğlu/Astarlı/Baysal, 2014: 290). 


\section{SONUÇ}

6012 sayılı Türk Ticaret Kanunu madde 178'de bölünmeye dayalı olarak gerçekleşen işyeri devri neticesinde işçilere sağlanan haklar bakımından bazı özel düzenlemelere yer verilmiştir. TTK madde $158^{\prime}$ de yapılan atıf dolayısıyla birleşmede, TTK madde 190 'da yapılan atıf dolayısıyla da tür değiştirmede TTK madde 178 hükmü uygulama alanı bulmaktadır. TTK madde 178 'in iK madde 6'dan daha sonra yürürlüğe girmiş olması; özel olarak birleşme, bölünme ve tür değiştirme hallerine uygulanacak olması; ayrıca gerekçesinde ve TBMM Komisyon Raporu'nda da belirtiliyor olması nedeniyle TTK madde 178'in birleşme, bölünme ve tür değiştirmede İK madde 6’ya göre özel hüküm niteliğinde olduğu kabul edilmelidir. İ madde 6 ise genel hüküm olarak uygulanmaya devam etmektedir.

TTK madde 178 ' de, ík madde 6 ' dan farklı olarak yapısal değişiklik neticesinde işçilere itiraz ve teminat talep etme hakkı verilmiştir. Ayrıca devreden ve devreden işverenlerin müteselsil sorumluluklarının kapsamı genişletilmiş, ortakların şahsi sorumluluklarına ilişkin hükümlere yer verilmiştir. Belirtmek gerekir ki tür değiştirme hali bakımından yalnızca TTK madde $178^{\prime}$ in ortakların şahsi sorumluluklarına ilişkin hükümleri uygulanabilecektir. Tür değiştirmede gerçek bir işveren değişikliği yaşanmadığından dolayı, iş̧̧ilere itiraz ve teminat talep etme hakkının verilmesine gerek duyulmadığı gibi, eski ve yeni işveren söz konusu olmadığından dolayı müteselsil sorumluluktan da bahsedilememektedir.

Iş̧̧ilerin birleşme ve bölünme hallerinde iş sözleşmelerinin yeni işverene geçmesini engellemeye yönelik itiraz hakları bulunmaktadır. İtiraz hakkı hiçbir şekilde birleşme ve bölünmeyi engellemeye yönelik değildir. İtiraz hakkı kullanıldığı takdirde belirli bir sürenin sonunda iş sözleşmesi kanun gereği sona ermektedir. TTK'da işverenlerin işçileri birleşme veya bölünmeyle ilgili bilgilendirme yükümlülükleri bulunmamaktadır. İtiraz hakkının kullanılması ise ancak işçinin bu durumlardan haberdar olması ile mümkündür. İş̧̧inin itiraz hakkını doğuran nedenlerin oluşmasından önce itiraz hakkından feragat edebilmesi mümkün değildir.

TTK madde 178'e göre itiraz hakkı kullanıldıktan sonra IK madde 17'de belirtilen kanuni bildirim süreleri sonunda sözleşme sona ermektedir. Bu hususta belirli ve belirsiz süreli iş sözleşmeleri bakımından ayrım yapılmamıştır. Ancak işçilerin bilgi sahibi olduktan sonra ne kadar süre içinde itiraz haklarını kullanabileceklerine dair kanunda düzenleme yer almamaktadır. Bu hususta doktrinde farklı görüşler ileri sürülmüştür. Bizim de katıldığımız görüşe göre işçilerin bilgi sahibi olmalarından başlayarak 1 ay içinde itiraz haklarını kullanmaları gerekmektedir. İşverenin bilgilendirme yükümlülüğü olmaması nedeniyle 1 aylık süre işçi ne zaman birleşme veya bölünmeyi öğrenirse o zaman başlamalıdır. Ancak TTK madde 157 ve madde 174'te alacaklılar için yapılacak ilanların işçilerin itiraz haklarını kullanmaları gereken sürenin başlangıcı olduğu kabul ileri sürülebilmelidir. Kanuni bildirim süreleri dolmadan önce birleşme veya bölünmenin gerçekleşmesi durumunda ise devralan işveren sürenin sonuna kadar sözleşmenin tarafı olmaktadır.

İtiraz neticesinde iş sözleşmesinin sona ermesi işçi veya işveren feshi olarak değil, kanundan kaynaklanan bir neden olarak kabul edilmektedir. Bu husus işçilerin özellikle kıdem tazminatına hak kazanmaları ile işsizlik sigortasından yararlanmaları bakımından problem oluşturmaktadır. İş sözleşmesinin TTK madde 178 uyarınca sona ermesi işçilerin kıdem tazminatı ile işsizlik sigortasına hak kazandıkları durumlar arasında sayılmamıştır. Ancak doktrindeki baskın görüşe göre bu haklardan yararlanmadan iş̧̧ilerin iş sözleşmelerini feshetme hakkı halihazırda zaten bulunmaktadır. İ madde 6’ya nazaran daha üstün haklar sağladığı iddia edilen madde 178 uyarınca iş sözleşmesinin itiraz nedeniyle sona ermesi halinde işçiler kıdem tazminatı ile işsizlik sigortasından faydalanmaya hak kazanmalıdırlar.

İş̧ilere tanınan itiraz hakkının tür değiştirmede mümkün olmadığı belirtilmiştir. Ayrıca devralma şeklindeki birleşmelerde devralan şirketin işçileri ile kısmi bölünmelerde devreden şirketin işçilerine itiraz hakkının tanınmadığı kabul edilmelidir. Çünkü söz konusu işçiler bakımından herhangi bir işveren değişikliği yaşanmamaktadır. Bu işçiler çalıştıkları işyerlerinde çalışmaya devam etmektedirler. Yeni kuruluş türünde birleşmeler ile tam bölünmelerde ise yapısal değişikliğe katılan tüm şirketler infisah ettiklerinden dolayı tüm işçilerin itiraz hakkı bulunmaktadır.

TTK madde 178'de TTK madde 178'deki düzenleme ile devreden ve devralan işverenlerin müteselsil sorumluluklarının kapsamı, iK madde 6'ya göre daha geniş tutulmuştur. Müteselsil sorumluluğun hangi zaman aralığı dahilinde muaccel olan alacakları kapsadığının belirlenmesi hususunda TTK madde 178/3'te işçinin itiraz etmesi veya etmemesine göre farklı düzenlemeler getirilmiştir. İş̧i itiraz ettiği takdirde eski işveren ile devralan işveren bölünmeden önce muaccel olmuş alacaklar ile işçinin itirazı sebebi ile sözleşmenin sona erdiği tarihe kadar geçen sürede muaccel olacak alacaklardan müteselsilen sorumludurlar.

İş̧̧i itiraz etmediği takdirde eski işveren ile devralan işveren, bölünmeden önce muaccel olmuş alacaklar ile hizmet sözleşmesinin normal olarak sona ereceği tarihe kadar geçen sürede muaccel olacak alacaklardan müteselsilen sorumludurlar. Bu bağlamda 
belirli süreli sözleşmeler bakımından belirli sürenin sonuna kadar doğacak alacakların müteselsil sorumluluğun kapsamına girdiği kabul edilmelidir. Ancak belirsiz süreli sözleşmeler bakımından normal olarak sona erme hali iş hukukunda ölüm olarak kabul edilmektedir. Bu nedenle doktrinde müteselsil sorumluluk bakımından makul bir sürenin tespiti gündeme gelmiştir. Bir görüşe göre sözleşme devir sırasında feshedilseydi, bildirim süreleri sonunda sözleşme en erken ne zaman sona erecek ise müteselsil sorumluluğun sınırı o tarih olmalıdır.

Kıdem tazminatı bakımından 1475 sayılı İ madde 14'ün özel hüküm olduğu kabul edilerek, devren işverenin kıdem tazminatı sorumluluğunun işçiyi çalıştırdığı süreler ve devir sırasında iş̧̧inin aldığı ücret seviyesiyle sınırlı olduğu kabul edilmelidir. Müteselsil sorumluluk tür değiştirmede söz konusu olmamaktadır. Yine birleşmenin her iki türünde ve tam bölünme halinde şirketler infisah ettiklerinden dolayı müteselsil sorumluluk hükümlerinin uygulanması mümkün değildir. Yalnızca kısmi bölünme halinde devreden ve devralan işveren arasında müteselsil sorumluluk hükümleri uygulanabilecektir.

TTK madde 157 'de birleşmede, TTK madde 174 'te ise bölünmede alacaklıların alacaklarının teminat altına alınmasına yönelik esaslar düzenlenmiştir. Buna göre yapılması öngörülen ilanlar sonrasında birleşmede birleşmenin geçerlilik kazanmasından itibaren 3 ay, bölünmede ise alacaklılar için yapılması öngörülen ilandan itibaren 3 ay içinde alacaklıların başvurması üzerine alacakların teminat alınması veya şirketin tercihine bağlı olarak diğer alacaklıların zarara uğramayacaklarının anlaşıması üzerine ödenmesi gerekmektedir. TTK madde 175/2 uyarınca bölünmede, alacaklıların alacaklarının tehlikeye düşmediğinin ispatı halinde teminat yükümlülüğü kalkmaktadır.

Teminat altına alınması gereken alacaklar ise birleşme ve bölünmeden önce muaccel olan alacaklardır. TTK madde $178 / 5$ 'te getirilen ve işçilerin alacaklarının teminat altına alınması düzenleyen hüküm ile teminat kapsamının genişletildiğini söylemek mümkündür. Ayrıca TTK madde 178'de yer verilen düzenleme ile TTK madde 157 veya TTK madde 175 uyarınca alacakların tümünü kapsayan tek teminat verilen durumlarda, işçilerin TTK madde 178 'e dayanarak ayrı ve özel teminat talep edebilmeleri mümkün hale gelmiştir. TTK madde 178 'de teminat talebi hususunda düzenlemelere yer verilmediğinden dolayı, TTK madde 157 ve TTK madde 174 'te öngörülen hükümlerden faydalanılması gerekmektedir.

Birleşmelerde devredilen şirket infisah ettiğinden dolayı teminatın devralan şirket tarafından verildiği kabul edilmektedir. Bölünmelerde ise teminat bölünmeden önce gösterileceğinden dolayı teminat talebi devreden şirkete yöneltilmelidir. Teminat talebi bakımından herhangi bir şekil şartı öngörülmemiştir. Teminatın türü ayni veya şahsi olabileceği gibi; taşınır veya taşınmaz üzerinde rehin hakları, 3. kişilere ait malvarlıkları üzerinde ayni teminat, ödeme gücü olan 3. kişinin kefaleti teminat olarak gösterilebilecektir. Alacaklıların birleşmeye veya bölünmeye engel olma hakları ise bulunmamaktadır. Devralma yoluyla birleşmelerde devralan şirketin ortakları ile kısmi bölünmelerde devreden şirketin ortaklarının TTK madde 178 kapsamında teminat talep etme hakları bulunmamaktadır. Ancak bu ortaklar genel hükümlere dayanarak daha dar kapsamda teminat talep edebilmelidirler.

TTK madde 178/6' da, tüm alacaklılar bakımından ortakların şahsi sorumluluklarını düzenleyen TTK madde $158^{\prime}$ den farklı olarak 3 yıllık zamanaşımı süresi öngörülmemiştir. Ancak TTK madde 177 hükmü uyarınca yine de 3 yıllık zamanaşımı süresinin uygulanması gerektiği ifade edilmektedir. Ayrıca TTK madde 158'de borcun birleşme kararından önce doğmuş olması veya borcu doğuran nedenlerin birleşme tarihinden önce oluşması gerekmekte iken, TTK madde 178'de hizmet sözleşmesi normal olarak sonra ermiş olsaydı muaccel hale gelecek, itiraz sebebiyle hizmet sözleşmesinin sona erdiği tarihe kadar ise muaccel olma şartı aranmadan yalnızca doğacak borçlardan ortakların sorumlu olmaya devam edecekleri hüküm altına alınmıştır.

TTK madde 236 ' da kollektif şirketlerde tüm ortakların, TTK madde 325'te komandit şirketlerde komandite ortakların, TTK madde 564 'te ise sermayesi paylara bölünmüş komandit şirketlerde bir ya da birkaç ortağın alacaklılara karşı şahsi sorumlu oldukları hüküm altına alınmıştır. Söz konusu ortaklık türleri anonim veya limited şirket türlerine dönüştüğü takdirde, ortakların şahsi sorumluluklarından bahsedilmesi mümkün olmayacaktır. Bu ihtimali göz önünde bulunduran kanun koyucu, birleşmeler bakımından TTK madde 158/1'de bazı şartlar altında devredilen şirketin borçlarından birleşmeden önce sorumlu olan ortakların sorumluluklarının birleşmeden sonra da devam edeceğini hüküm altına almıştır. Aynı sonuç TTK madde 194/2 uyarınca ticaret şirketine dönüşmesi mümkün olan ticari işletmeler bakımından da geçerli olmalıdır. 


\section{KAYNAKÇA}

Albayrak Zincirlioglu, C. (2014). İşyerinin Devrinde Türk Ticaret Kanunu ile İş Kanunu Hükümlerinin İş iliş̧ilerine Etkisi. TBB Dergisi. $114,11-48$.

Alp, M. (2012). Yeni Türk Ticaret Kanunu'na Göre Bölünme, Birleşme ve Tür Değiştirmenin İş iliş̧ilerine Etkisi (TTK 178; 158; 190). Çalışma ve Toplum. 1, 51-74.

Astarlı, M. (2013). Karşılaştırmalı Hukukta ve Türk Hukukunda İşyeri Devrinde İşçinin İş İlişkisinin Devralan İşverene Geçişine İtiraz Hakkı. Çalışma ve Toplum. 1, 69-106.

Cakrak, R. (2017). Ticari Şirketlerin Yapı Değişikliği Sonucunda İş İlişkisinin Geçmesi: Teminat Talep Etme Hakkı ve Müteselsil Sorumluluk. Karatahta/iş Yazıları Dergisi. 9, 107-124.

Celik, N. \& Caniklioglu N. \& Canbolat, T. (2019). İş Hukuku Dersleri, 32. Bası. İstanbul, Beta Yayınevi.

Ekmekçi, O. (2011). Şirketlerin Bölünmesi, Birleşmesi ve Tür Değiştirmesinin İş İlişkilerine Etkisi İş Kanunu/Türk Borçlar Kanunu-Türk Ticaret Kanunu Çelişkisi. Sicil iş Hukuku Dergisi. 24, 154-159.

Eren, F. (2012). Borçlar Hukuku Genel Hükümler, 14. Baskı. Ankara, Yetkin Yayınevi.

Gundogdu, G. \& Kaplan, H. A. (2011). İsviçre ve Alman Hukuku Işığında Yeni Türk Ticaret Kanunu madde 147 f. 2-i Hükmünde Öngörülen Sosyal Plan Kavramı, Sicil iş Hukuku Dergisi. 24, 160-171.

Gundogdu, G. \& Kaplan, H. A. (2011). Türk Ticaret Kanunu Tasarısı'nda Bölünmenin İş İlişkilerine Etkisi, Iş Dünyası ve Hukuk-Prof. Dr. Tankut Centel'e Armağan, 1010-1031.

Kayık Aydınalp, A. (2017). İş Hukuku Açısından Ticaret Şirketlerinde Yapısal Değişiklikler. İstanbul, Beta Yayınevi.

Kendigelen, A. (2012). Türk Ticaret Kanunu Değişiklikler, Yenilikler ve İlk Tespitler, 2. Bası. İstanbul, On İki Levha Yayıncılık.

Kendigelen, A. (2016). Türk Ticaret Kanunu ve İlgili Mevzuat, 4. Bası. İstanbul: On İki Levha Yayıncılık.

Mollamahmutoglu H. \& Astarlı, M. \& Baysal, U. (2014). İş Hukuku, 6. Bası. Ankara, Turhan Kitabevi.

Narbay, S. \& Kesici, B. (2015). Ticaret Ortaklıklarında Yapısal Değişiklik Kararına Karşı Öngörülen İptal Davası Üzerine Karşılaştırmalı Bir İnceleme. TFM. 152, 107-160.

Ozkaraca, E. (2012). Şirketlerin Birleşmesi, Bölünmesi ve Tür Değiştirmesinin İş Hukukuna Etkileri. Iş Hukukunda Güncel Sorunlar (2), $103-172$.

Poroy, R. \& Tekinalp, U. \& Camoglu, E. (2014). Ortaklıklar Hukuku I, 13. Bası. İstanbul: Vedat Kitapçılık.

Senyen Kaplan, E. T. (2013). İşyeri Devrinin, Türk Ticaret Kanunu madde 178 ve İş Kanunu madde 6 Hükümleri Çerçevesinde İş iliş̧kilerine Etkisi. Sicil iş Hukuku Dergisi. 29, 24-39.

Suzek, S. (2014). İşyerinin Devri ve Hukuki Sonuçları. DEÜHFD. 15, 311-330.

Suzek, S. (2019). İş Hukuku, 18. Bası. İstanbul, Beta Yayınevi.

Sener, O. H. (2012). Teorik ve Uygulamalı Ortaklıklar Hukuku. Seckin Yayıncılık.

www.lexpera.com.tr 